\title{
Productividad de asociaciones de pasto ovillo (Dactylis glomerata L.), ballico perenne (Lolium perenne L.) y trébol blanco (Trifolium repens L.)
}

\author{
Performance of orchardgrass (Dactylis glomerata $L$ ), \\ perennial ryegrass (Lolium perenne L.) and white clover \\ (Trifolium repens L.) associations
}

\author{
Ever del J. Flores Santiagoa, Alfonso Hernández Garaya, J uan de Dios Guerrero \\ Rodríguezb, Adrián R. Quero Carrilloa, Pedro A. Martínez Hernándezc
}

\begin{abstract}
RESUMEN
El objetivo del estudio fue evaluar el rendimiento de forraje de los pastos, ovillo (Dactylis glomerata L.) y ballico perenne (Lolium perenne L.) en monocultivo y asociados con trébol blanco (Trifolium repens L.), en su segundo año de crecimiento. Los tratamientos evaluados fueron: 20:40:40; 00:50:50; 40:20:40; 50:00:50; 20:70:10; 70:20:10, 40:40:20, 100:00:00 y 00:100:00 de pasto ovillo, ballico perenne y trébol blanco, respectivamente. El diseño experimental fue bloques al azar con tres repeticiones. Se midió rendimiento de forraje, altura de planta, radiación interceptada $(R I, \%)$ y composición botánica del forraje cosechado (\%). Los tratamientos se defoliaron por ovinos (Suffolk $x$ Dorset) de acuerdo con la estación del año (cada cinco, seis y cuatro semanas en otoño, invierno y primavera-verano, respectivamente). Las asociaciones 00:50:50, 20:40:40, y 40:20:20 tuvieron una diferenciación mayor en rendimiento anual produciendo más del $22 \%$ que los monocultivos de pastos y la asociación 40:40:20 que presentaron los menores rendimientos (en promedio $15,027 \mathrm{~kg}$ MS ha-1). La producción estacional tuvo diferente $(P<0.05)$ aportación durante el año; en otoño-inviemo se produjo el $40 \%$ y en primavera-verano $60 \%$. El trébol blanco fue la especie con mayor porcentaje del forraje cosechado (44\%) seguida por pasto ovillo (39 \%) y ballico perenne (17 \%). En conclusión, algunas asociaciones superaron el rendimiento de los pastos en monocultivo, existiendo diferencias también en la distribución estacional de la producción de forraje. La intercepción de radiación y altura de la planta son indicativos del rendimiento, y por tanto del momento de cosecha.
\end{abstract}

PALABRAS CLAVE: Materia seca, Asociaciones, Gramíneas, Leguminosas, Composición botánica.

\begin{abstract}
The aim of this study was to evaluate the forage yield of orchargrass (Dactylis glomerata L.) and perennial ryegrass (Lolium perenne L.) in monoculture and associated with white clover (Trifolium repens L.), in its second year of establishment. The treatments were: 20:40:40, 00:50:50, 40:20:40, 50:00:50, 20:70:10, 70:20:10 and 40:40:20 of orchard grass, perennial ryegrass and white clover, respectively. These associations were distributed according to a randomized block design with three replications. The variables measured were forage yield, plant height, radiation interception (RI, \%) and botanical composition of the harvested fodder (\%). All treatments were defoliated by sheep (Suffolk $x$ Dorset) according to each season of the year (five, six and four weeks in autumn, winter and springsummer, respectively). The associations 00:50:50, 20:40:40, and 40:20:20 had the higher annual herbage yield producing $22 \%$ more than the grass monocultures and the 40:40:20 association which had the lowest DM yields (on average $15,027 \mathrm{~kg}$ MS ha-1). Seasonal production throughout the year was distributed as follows: in fall-winter $40 \%$ and spring-summer $60 \%(P<0.05)$. White clover was the species with the highest percentage of harvested forage (44\% ) followed by orchardgrass (39\%) and perennial ryegrass $(17 \%)$. In conclusion, some of the associations surpassed the yield of grasses in monoculture; additionally, there was a differentiation in the seasonal forage production. The interception of solar radiation and plant height are good indicative of yield and therefore of harvest.
\end{abstract}

KEY WORDS: Dry matter yield, Grass-legume associations, Botanical composition.

\footnotetext{
Recibido el 10 de septiembre de 2013. Aceptado el 19 de marzo de 2014.

a Programa de Ganadería, Colegio de Postgraduados Campus Montecillo. México. hernan@colpos.mx. Correspondencia al segundo autor.

b Colegio de Postgraduados Campus Puebla. México.

c Departamento de Zootecnia, Universidad Autónoma Chapingo. México.
} 
En la zona templada de México, los pastos más utilizados para la producción animal, son el ballico perenne, el ovillo y el festuca, de los que se estima existen en praderas puras y en asociación alrededor de 171,520 ha que representan el $13.4 \%$ de la superficie total de esta zona(1), tendencia que actualmente se mantiene. Así mismo, entre las leguminosas, se tiene a la alfalfa y el trébol blanco, donde esta última especie es de alta calidad nutritiva y tiene requerimientos menores de agua que la primera $(2,3)$. En general, las asociaciones gramíneas-leguminosas mejoran la distribución estacional del rendimiento de la pradera(4).

Se ha observado que la asociación de trébol blanco a una proporción de $40 \%$ con pasto ovillo y ballico perenne ha llegado a rendir de 52 hasta $65 \%$ más de forraje que cuando estos pastos se encuentran en monocultivo(5). Estos rendimientos de materia seca se han obtenido en primavera-verano a un intervalo de corte de 28 días y en otoño e invierno a intervalos de 5 y 6 semanas respectivamente(5), en condiciones de pastoreo con ovinos. Lo anterior, sugiere que la cantidad y calidad del forraje cosechado puede ser mayor y sostenible con la asociación trébol blanco-gramíneas(5). Sin embargo, el porcentaje de trébol y gramínea puede afectar la cantidad de forraje cosechado en cada estación del año(6), como consecuencia de la competencia entre componentes botánicos de la pradera(7).

En asociaciones de gramíneas y leguminosas es importante determinar la mejor asociación desde el punto de vista de rendimiento anual, distribución estacional, valor nutritivo y persistencia de la pradera. En la región templada de México, los patrones estacionales de producción de forraje están influenciados por variaciones en el clima, por lo que es importante conocer la velocidad de crecimiento estacional de las especies forrajeras más utilizadas. Por tal motivo, el objetivo de esta investigación fue determinar la mejor asociación a diferentes proporciones de pasto ovillo, ballico perenne y
In the temperate zone of Mexico, the most used grasses for animal production are perennial ryegrass, orchardgrass and fescue, where around an estimated 171,520 ha exist in pure monocultures and in grassland associations, they represent $13.4 \%$ of the total area of this zone $^{(1)}$, and at present, this still endures. Likewise, among the legumes, there is alfalfa and white clover, where the latter specie is of high nutritional quality and has lower water requirements than the first $(2,3)$. In general, grass-legume associations improve the seasonal distribution of yield of the meadow(4).

It has been observed that the association of white clover at a proportion of $40 \%$ with orchardgrass and perennial ryegrass can reach yields of 52 to $65 \%$ more than pure forage grasses(5). These dry matter yields were obtained in spring-summer with a cutting interval of $28 \mathrm{~d}$ and in autumn and winter at intervals of 5 and $6 w k$, respectively(5), under grazing with sheep. This suggests that the quantity and quality of harvested forage may be higher and sustainable with white clover-grass association(5). However, the percentage of clover and grass can affect the amount of forage harvested in each season(6) as a result of competition between botanical components in the sward(7).

In associations of grasses and legumes it is important to determine the best association from the point of view of annual herbage yield, seasonal distribution, nutritional value and sward persistence. In the temperate region of Mexico, seasonal forage production patterns are influenced by variations in climate, thus it is important to know the speed of seasonal growth of forage species most used. Therefore, the objective of this research was to determine the best association in different proportions of orchardgrass, perennial ryegrass and white clover, from the point of view of seasonal and annual herbage yield.

The study was conducted at the Experimental Station of the Colegio de Postgraduados in 
trébol blanco, desde el punto de vista de rendimiento estacional y anual.

El estudio se realizó en el Campo Experimental del Colegio de Posgraduados Campus Montecillo, Texcoco, Estado de México, en praderas de pasto ovillo y ballico perenne, puras y asociadas con trébol blanco, en su segundo año de crecimiento. El suelo es Typic ustipsamments(8) de textura franco arenosa, ligeramente alcalino $(\mathrm{pH} 7.8)$, $2.4 \%$ de materia orgánica. El clima es templado subhúmedo con lluvias en verano, precipitación y temperatura media anual de $645 \mathrm{~mm}$ y 15 ${ }^{\circ} \mathrm{C}$, respectivamente y temperatura mínima promedio mensual de $11.6{ }^{\circ} \mathrm{C}$ y máxima de $18.4{ }^{\circ} \mathrm{C}$, registradas en enero y mayo, respectivamente( 9 ). Las temperaturas máximas, mínimas y medias, así como la distribución de la precipitación del periodo de estudio se obtuvieron de la estación meteorológica del Colegio de Postgraduados, ubicada a $100 \mathrm{~m}$ del área experimental (Figura 1).

Los tratamientos evaluados fueron los pastos ovillo y ballico perenne, solos y asociados con trébol blanco a diferentes proporciones: 100:00:00, 00:100:00, 20:40:40, 0:50:50, 40:20:40, 50:00:50, 20:70:10, 70:20:10, y 40:40:20 pasto ovillo, ballico perenne y trébol blanco, respectivamente. Estas proporciones se basaron en la cantidad de semilla recomendadas para cada especie, siendo de $30 \mathrm{~kg}$ ha-1 para ballico perenne, $20 \mathrm{~kg} \mathrm{ha}^{-1}$ de ovillo, y de $5 \mathrm{~kg}$ ha-1 para trébol blanco. Estas cantidades de semilla fueron el $100 \%$ para las especies individualmente, de modo que, para el caso de las asociaciones, se obtuvo el porcentaje respectivo en cada participación. El diseño experimental fue bloques completos al azar con tres repeticiones, el bloqueo fue por pendiente natural del terreno; la unidad experimental fue una parcela de $75.03 \mathrm{~m}^{2}(12.3 \times 6.1 \mathrm{~m})$. Las parcelas no fueron fertilizadas pero sí irrigadas en la época de seca e invierno, a intervalos de 15 días. Las parcelas se delimitaron con cerco eléctrico y defoliadas con ovinos Suffolk*Dorset a $5 \mathrm{~cm}$ de altura, cada cinco, seis y cuatro
Montecillo, Texcoco, State of Mexico, in orchard grass and perennial ryegrass swards alone and associated with white clover, in its second year of growth. The soil is Typic ustipsamments(8) composed of sandy loam, slightly alkaline $(\mathrm{pH}$ 7.8), with $2.4 \%$ organic matter. The climate is temperate humid with summer rainfall, with precipitation and mean annual temperature of $645 \mathrm{~mm}$ and $15^{\circ} \mathrm{C}$, respectively, with minimum monthly average temperature of $11.6^{\circ} \mathrm{C}$ and maximums of $18.4{ }^{\circ} \mathrm{C}$, recorded in J anuary and May, respectively $(9)$. The maximum, minimum and average temperatures and precipitation distribution during the study period were obtained from the meteorological station of the Graduate College, located $100 \mathrm{~m}$ from the experimental area (Figure 1).

The treatments evaluated were orchard grass and perennial ryegrass alone and associated with white clover at different proportions: 100:00:00, 00:100:00, 20:40:40, 0:50:50, 40:20:40, 50:00:50, 20:70:10, 70:20:10, and 40:40:20 orchard grass, perennial ryegrass and white clover, respectively. These proportions of

Figura 1. Características climáticas durante el periodo de estudio. Aplicación de riego $(\downarrow)$

Figure 1. Climatic characteristics during the study period. Application of irrigation ( $\downarrow$ )

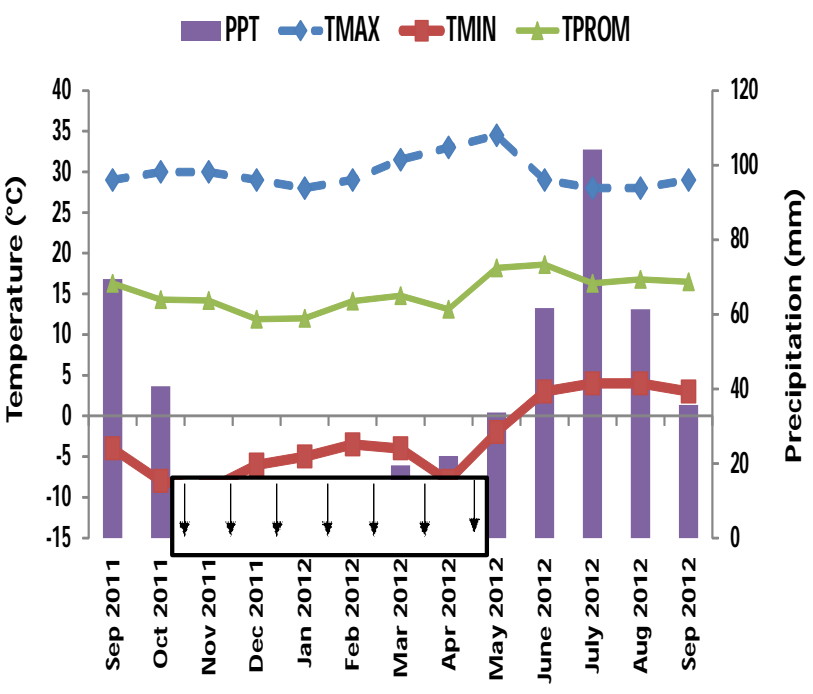


semanas en otoño, invierno y primavera-verano, respectivamente(10,11).

Variables medidas y calculadas en la pradera Rendimiento de forraje. El rendimiento de forraje se midió en dos cuadros fijos de $0.25 \mathrm{~m}^{2}$ en los que se cortó el forraje con tijeras antes del pastoreo, a una altura aproximada de $5 \mathrm{~cm}$ sobre el nivel del suelo. Inmediatamente después, las praderas se defoliaron por ovinos a una altura aproximada de $5 \mathrm{~cm}$. El forraje cosechado se lavó para eliminar tierra, posteriormente se secó en estufa de aire forzado por $48 \mathrm{~h}$ a $55^{\circ} \mathrm{C}$, hasta peso constante y se pesó. Con los registros de peso seco se calculó el rendimiento anual y estacional para cada tratamiento.

Altura de la pradera. Se midió antes de cada pastoreo con una regla de $1 \mathrm{~m}$ de longitud $\mathrm{y}$ graduación mínima de $1 \mathrm{~mm}$. Se eligieron aleatoriamente 20 puntos por parcela, y la regla se aproximó verticalmente hacia el tejido vegetal más alto, para registrar la altura de la primera especie contactada(12).

Radiación interceptada. Un día antes de cada pastoreo, se tomaron al azar cinco lecturas por repetición de la radiación interceptada con el método del metro de madera sobre el suelo(13). Las lecturas se realizaron aproximadamente a las $1300 \mathrm{~h}$ (cuando el ángulo solar es alto y constante). El procedimiento consistió en colocar la regla en la superficie del suelo debajo del dosel, con orientación este-oeste. En cada ocasión se contaron los centímetros sombreados, mismos que al ser divididos entre la longitud total de la regla, representaron el porcentaje de radiación interceptada por el dosel.

Composición botánica. A la mitad de cada estación, de las muestras cosechadas para medir el rendimiento de MS se tomaron $20 \%$, y las plantas se clasificaron y separaron por especie en estudio, material muerto, otros pastos y maleza. Las muestras de cada componente se secaron a $55^{\circ} \mathrm{C}$ por $48 \mathrm{~h}$ hasta peso constante, y luego se pesaron. seeds were based on the amount recommended for each species, being $30 \mathrm{~kg} \mathrm{ha}^{-1}$ for perennial ryegrass, $20 \mathrm{~kg} \mathrm{ha-1}$ orchardgrass, and $5 \mathrm{~kg}$ $\mathrm{ha}^{-1}$ for white clover. These amounts of seed were $100 \%$ values for individual species; hence, in the case of associations, the number of seeds was determined based on these respective percentages. The experimental design was a randomized complete block design with three replications, blocking was by natural slope of the land; the experimental unit was a plot of $75.03 \mathrm{~m}^{2}(12.3 \times 6.1 \mathrm{~m})$. The plots were not fertilized and were irrigated in the dry season and winter, at intervals of $15 \mathrm{~d}$. The plots were delimited with electric fences and defoliated with Suffolk*Dorset sheep at $5 \mathrm{~cm}$ sward height, every 5, 5 and 4 wk in autumn, winter and spring and summer, respectively $(10,11)$.

Variables measured and calculated in the sward

Forage yield. Herbage yield was measured in two fixed frames of $0.25 \mathrm{~m}^{2}$ where forage is cut with scissors before grazing, to a height of $5 \mathrm{~cm}$ above the ground. Immediately after, sheep defoliated the swards to a height of $5 \mathrm{~cm}$. The harvested sample was washed to remove dirt, then dried in a forced air oven for $48 \mathrm{~h}$ at 55 ${ }^{\circ} \mathrm{C}$ to a constant weight and weighed. With dry weight data, the annual and seasonal herbage yield for each treatment was calculated.

Sward height. Was measured before each grazing with a ruler $1 \mathrm{~m}$ in length and graduated with $1 \mathrm{~mm}$ increments. For each plot 20 points were randomly selected, and the rule was aligned vertically at the highest part of the plant tissue, to record the height of the first contacted species(12).

Intercepted radiation. One day before each grazing, five readings were randomly taken per repetition of the intercepted radiation by the method of a meter stick above the ground(13). Readings were performed at approximately $1300 \mathrm{~h}$ (when the sun is high and at a constant angle). The procedure consisted of placing the 
Se verificaron las condiciones de normalidad de todas las variables y posteriormente se realizó el análisis estadístico para cada variable por estación del año mediante el procedimiento PROC MIXED del paquete estadístico SAS(14) declarando como factor aleatorio a los tratamientos. Para la comparación de medias por tratamiento se utilizó la prueba de Tukey con $\alpha$ de $5 \%$.

El rendimiento anual fue diferente entre tratamientos, en donde las asociaciones 00:50:50, 20:40:40, 40:20:40 superaron $(P<0.05)$ a los monocultivos en al menos 22 y $33 \%$ al ballico perenne y al ovillo, respectivamente (Cuadro 1). Estas diferencias fueron más marcadas durante las estaciones de invierno y primavera, donde los dos pastos mostraron rendimientos bajos, principalmente, el ovillo que alcanzó una producción anual de $13,280 \mathrm{~kg} \mathrm{MS} \mathrm{ha-1}$ año-1. Entre estaciones, los rendimientos acumulados sin considerar el tipo de asociación, fueron diferentes; específicamente, los mayores rendimientos se encontraron en primavera y verano (Cuadro 1 ) superando $(P<0.05)$ a las estaciones de otoño e invierno en al menos 35 y $29 \%$ más, respectivamente. Independientemente de las asociaciones, la producción estacional de materia seca fue de 19, 21, 30 y $30 \%$, para otoño, invierno, primavera y verano, respectivamente. ruler on the soil surface under the canopy, in an east-west direction. Each time the shaded centimeters were measured were then divided by the total length of the ruler, representing the percentage of radiation intercepted by the canopy.

Botanical composition. In the middle of each season, a subsample of about $20 \%$ was taken from the sample used to measure herbage yield, and the plants were classified and separated by species studied, dead material, other grasses and weeds. Samples of each component was dried at $55^{\circ} \mathrm{C}$ for $48 \mathrm{~h}$ to constant weight, and then weighed.

Normality conditions of all variables were checked and then statistical analysis was performed for each variable by season using the PROC MIXED procedure of the SAS statistical package (14) using treatment as the random factor. Tukey test with $\alpha$ of $5 \%$ was used to compare the means of the treatments.

The annual herbage yield was different between treatments, where associations 00:50:50, 20:40:40, 40:20:40 exceeded $(P<0.05)$ by at least by 22 and $33 \%$ compared to the perennial ryegrass and orchard grass pure swards, respectively (Table 1 ). These differences were more marked during the winter and spring, where the two grasses showed low yields, mainly

Cuadro 1. Rendimiento estacional y anual $\left(\mathrm{kg} \mathrm{MS} \mathrm{ha}^{-1}\right)$ de diferentes proporciones en la asociación de dos gramíneas con una leguminosa

Table 1. Seasonal and annual herbage yield ( $\left.\mathrm{kg} \mathrm{DM} \mathrm{ha}^{-1}\right)$ with different proportions in the associations of two grasses and a legume

\begin{tabular}{|c|c|c|c|c|c|c|c|c|c|c|c|}
\hline \multirow[b]{2}{*}{ Season } & \multicolumn{10}{|c|}{ Proportion of grass associations (orchardgrass-perennial ryegrass-white clover) } & \multirow[b]{2}{*}{ Mean } \\
\hline & $20: 40: 40$ & $00: 50: 50$ & 00:100:00 & $40: 20: 40$ & 50:00:50 & 20:70:10 & $70: 20: 10$ & 100:00:00 & $40: 40: 20$ & SEM & \\
\hline Fall & $3897 \mathrm{ABb}$ & $4073 \mathrm{Ac}$ & $3261 \mathrm{ABb}$ & $3435 \mathrm{ABC}$ & $3153 \mathrm{ABC}$ & $3185 \mathrm{ABC}$ & $3627 \mathrm{ABb}$ & $3318 \mathrm{ABab}$ & $2692 \mathrm{Bb}$ & 86 & $3405 c$ \\
\hline Winter & $3999 \mathrm{Ab}$ & $4603 \mathrm{Abc}$ & $3283 \mathrm{BCb}$ & $4483 \mathrm{Abc}$ & $4066 \mathrm{Abc}$ & $4125 \mathrm{Abc}$ & $3421 \mathrm{ABb}$ & $2429 \mathrm{Bb}$ & $3346 \mathrm{ABb}$ & 143 & $3751 \mathrm{~b}$ \\
\hline Spring & $6121 \mathrm{Aa}$ & $5973 \mathrm{Aa}$ & 3978 BCab & $6264 \mathrm{Aa}$ & $5887 \mathrm{Aa}$ & $5749 \mathrm{Aa}$ & $5156 \mathrm{ABa}$ & $3516 \mathrm{Cab}$ & $4923 \mathrm{ABa}$ & 191 & $5285 a$ \\
\hline Summer & $5889 \mathrm{Aa}$ & $5660 \mathrm{Aab}$ & $4928 \mathrm{ABa}$ & $5703 \mathrm{Aab}$ & 5308 ABab & 5197 ABab & $5286 \mathrm{ABa}$ & $4017 \mathrm{Ba}$ & $5390 \mathrm{Aa}$ & 140 & $5264 \mathrm{a}$ \\
\hline SEM & 335 & 250 & 252 & 345 & 328 & 322 & 278 & 198 & 339 & & \\
\hline Annual & $19906 \mathrm{~A}$ & 20309 A & $15450 \mathrm{BC}$ & $19885 \mathrm{~A}$ & $18414 \mathrm{AB}$ & $18256 \mathrm{AB}$ & $17490 \mathrm{AB}$ & $13280 \mathrm{C}$ & $16351 \mathrm{BC}$ & & \\
\hline
\end{tabular}

$\mathrm{ABC}$, abc Means with the same capitalized letter per row are not different $(P>0.05)$ and mean with the same lowercase letter along a column are not different $(P>0.05$; Tukey, 0.05$)$. $\mathrm{SEM}=$ standard error of the mean. 
En la aportación por especie en asociación, el trébol blanco mostró significancia $(P<0.001)$ en las estaciones de primavera y verano (Cuadro 2). Consistentemente, la asociación 40:40:20, en ambas estaciones tuvo los rendimientos de materia seca más bajos $(P<0.05)$. En términos anuales, los aportes menores del trébol blanco correspondieron a las asociaciones donde hubo menor porcentaje en la asociación, espećficamente en donde participó con valores inferiores a $20 \%$ en la densidad de siembra.

El aporte del pasto ovillo sólo fue significativo $(P<0.001)$ en la estación de verano, siendo menor $(P<0.05)$ donde participó con una proporción menor (asociación 20:70:10). Asimismo, esta especie fue más productiva $(\mathrm{P}<0.05)$ durante la primavera y el verano. La orchardgrass with an annual output of 13,280 $\mathrm{kg} \mathrm{DM} \mathrm{ha-1} \mathrm{yr}^{-1}$. Between seasons, cumulative returns regardless of the type of association, were different $(P<0.001)$; specifically, the highest yields were found in spring and summer (Table 1) exceeding $(P<0.05)$ autumn and winter by at least 35 and $29 \%$, respectively. Regardless of associations, seasonal dry matter production was $19,21,30$ and $30 \%$, for fall, winter, spring and summer, respectively.

The contribution of each species in associations with white clover showed significant differences $(P<0.001)$ in the spring and summer (Table 2). Consistently, the association 40:40:20 for both seasons had lower dry matter yields $(P<0.05)$. In annual terms, the lower yield of white clover corresponded to associations where there were

Cuadro 2. Rendimiento estacional y total de diferentes proporciones en la asociación de dos gramíneas con una leguminosa (kg MS ha-1)

Table 2. Seasonal and total herbage yield with different proportions in the associations of two grasses and a legume (kg DM ha-1)

\begin{tabular}{|c|c|c|c|c|c|c|c|c|c|c|c|}
\hline \multirow[b]{2}{*}{ Season } & \multicolumn{9}{|c|}{ Proportion of grass associations (orchardgrass-perennial ryegrass-white clover) } & \multirow[b]{2}{*}{ SEM } & \multirow[b]{2}{*}{ Mean } \\
\hline & $20: 40: 40$ & $00: 50: 50$ & 00:100:00 & $40: 20: 40$ & $50: 00: 50$ & $20: 70: 10$ & $70: 20: 10$ & 100:00:00 & $40: 40: 20$ & & \\
\hline \multicolumn{12}{|c|}{ White clover } \\
\hline Fall & 1403 & 2539 & - & 1732 & 1799 & 1348 & 896 & - & 814 & 158 & $1054 b$ \\
\hline Winter & 1569 & 2740 & - & 2664 & 2420 & 2877 & 979 & - & 1048 & 207 & $2042 a$ \\
\hline Spring & $2298 \mathrm{AB}$ & $4252 \mathrm{~A}$ & - & 2499 AB & $2782 A B$ & 2011 B & 1204 B & - & 1301 B & 251 & $2335 a$ \\
\hline Summer & 3304 A & $3205 A B$ & - & $1635 \mathrm{AB}$ & $2161 A B$ & $2007 A B$ & $1432 \mathrm{AB}$ & - & 1319 B & & $2151 \mathrm{a}$ \\
\hline SEM & 298 & 254 & - & 175 & 197 & 199 & 194 & - & 133 & & \\
\hline Total & 8575 ABC & $12735 \mathrm{~A}$ & - & $8530 \mathrm{ABC}$ & $9163 \mathrm{AB}$ & 8244 BC & $4509 \mathrm{C}$ & - & 4482 C & & \\
\hline \multicolumn{12}{|c|}{ Orchardgrass } \\
\hline Fall & 754 & - & - & 933 & 946 & 971 & 1500 & 2495 & 723 & 149 & $1189 \mathrm{~b}$ \\
\hline Winter & 1071 & - & - & 1346 & 1208 & 923 & 1247 & 1791 & 1314 & 102 & $1271 b$ \\
\hline Spring & 2565 & - & - & 3178 & 2671 & 2362 & 2983 & 3116 & 2623 & 144 & $2785 a$ \\
\hline Summer & $2462 A B$ & - & - & $1316 \mathrm{AB}$ & $2921 A B$ & 1078 B & $2214 A B$ & 3743 A & 2048 AB & 332 & $2255 a$ \\
\hline SEM & 265 & - & - & 400 & 311 & 288 & 358 & 242 & 315 & & \\
\hline Total & $6852 A B$ & - & - & $6773 \mathrm{AB}$ & $7746 \mathrm{AB}$ & 5334 B & 7944 AB & 11145 A & 6709 AB & & \\
\hline \multicolumn{12}{|c|}{ Perennial ryegrass } \\
\hline Fall & 716 & 726 & 1781 & 510 & - & 445 & 554 & - & 491 & 197 & 746 \\
\hline Winter & $890 A B$ & $1502 \mathrm{AB}$ & 2629 A & $224 B$ & - & $95 \mathrm{~B}$ & $591 A B$ & - & $489 A B$ & 110 & 917 \\
\hline Spring & $617 \mathrm{AB}$ & $1136 \mathrm{AB}$ & $2884 \mathrm{~A}$ & $62 C$ & - & $988 \mathrm{AB}$ & $605 A B$ & - & $587 \mathrm{AB}$ & 216 & 983 \\
\hline Summer & 40 & 297 & 2233 & 1030 & - & 1831 & 995 & - & 1471 & 281 & 1128 \\
\hline SEM & 142 & 171 & 167 & 232 & - & 288 & 262 & - & 243 & & \\
\hline Total & $2263 B$ & 3662 B & $9527 \mathrm{~A}$ & $1826 \mathrm{~B}$ & - & 3359 B & $2745 B$ & - & 3038 B & & \\
\hline
\end{tabular}

$\mathrm{ABC}$, abc Means with the same capitalized letter per row are not different $(P>0.05)$ and mean with the same lowercase letter along a column are not different $(P>0.05$; Tukey, 0.05$)$. $\mathrm{SEM}=$ standard error of the mean. 
PRODUCTIVIDAD DE ASOCIACIONES DE OVILLO, BALLICO Y TRÉBOL

cantidad de materia seca cosechada de pasto ovillo en las asociaciones durante el periodo de evaluación fue en promedio de $7,500 \mathrm{~kg} \mathrm{MS}$ ha-1 (Cuadro 2). Independientemente del porcentaje de inclusión de ovillo en las asociaciones, el rendimiento total fue de $67 \%$ en primavera-verano y $33 \%$ en otoño-invierno, respectivamente $(\mathrm{P}<0.05)$.

En primavera-verano, ovillo incrementó su producción de materia seca, destacando el aporte de las asociaciones 40:20:40, 70:20:10 de pasto ovillo, ballico perenne y trébol blanco en primavera y 50:00:50 en verano, en las cuales el porcentaje de inclusión en la asociación fue mayor (Cuadro 2), aunado quizás a una mayor tasa de crecimiento y disminución en la pérdida por senescencia(15-19) y a las condiciones ambientales en las que creció durante el periodo de estudio.

Por su parte el ballico perenne, presentó significancias en aporte en las estaciones de invierno y primavera, aunque anualmente fue el más estable en contribución de materia seca independientemente de la asociación. La cantidad de materia seca de ballico perenne cosechado en las asociaciones fue en promedio de 2,816 kg MS ha-1, la cual representó un $17 \%$ de la cantidad total de forraje cosechada durante el año (Cuadro 2). No se detectó diferencia $(P>0.05)$ entre estaciones en el rendimiento de forraje de las asociaciones con ballico perenne; aun cuando se cosechó menos materia seca en el otoño, tal como lo han reportado algunos autores(5). Entre tratamientos durante otoño y verano no se encontró diferencia $(P>0.05)$. Se observa por tanto, que las especies trébol blanco y ovillo fueron las que diferenciaron las asociaciones en términos de producción de materia seca.

La variación en el rendimiento estacional se atribuye en parte a la respuesta de las especies a las condiciones ambientales en las cuales crecieron(20). La mayor adaptación de ballico perenne a condiciones invernales explica en parte el por qué algunas asociaciones fueron the percentage of associations was lower, specifically with seeding values of $20 \%$ or lower.

The yield contribution of orchardgrass was only significant $(P<0.001)$ in the summer season, and is lower $(\mathrm{P}<0.05)$ when associated in lower proportions (association 20:70:10). Also, this specie was more productive $(P<0.05)$ during the spring and summer. The amount of dry matter harvested from orchardgrass with associations during the evaluation period averaged 7,500 kg DM ha-1 (Table 2). Regardless of the percentage of inclusion of orchardgrass with associations, the total yield was $67 \%$ during spring-summer and $33 \%$ in autumnwinter, respectively $(P<0.05)$.

In the spring and summer, orchardgrass had higher production of dry matter with associations of 40:20:40, 70:20: 10 of orchardgrass, ryegrass and white clover in the spring, and 50:00:50 in the summer, in which the percentage of orchardgrass seed in the association was higher (Table 2). Perhaps the higher growth rate was caused by favorable environmental conditions during the study period with a decreased loss of senescence(15-19).

For its part, perennial ryegrass, presented significances in contribution in the winter and spring, although it was the most stable in terms of annual contribution of dry matter regardless of the association. The amount of dry matter harvested with perennial ryegrass associations averaged 2,816 kg DM ha-1, which represented $17 \%$ of the total amount of harvested forage during the year (Table 2). No difference ( $P>0.05$ ) were detected between seasons with herbage yield associations of perennial ryegrass; even when less dry matter was harvested in the fall, as some authors have reported(5). Between treatments during autumn and summer there was no difference $(P>0.05)$. It was observed that white clover and orchard grass associations differed in terms of dry matter production.

The seasonal variation of yield is attributed in part to the response of species to environmental 
superiores a otras en otoño-invierno, contrario a ovillo y trébol blanco que expresan su mayor rendimiento en condiciones de primavera-verano. La menor producción en otoño-invierno (Cuadro 1 ), puede ser atribuida a las bajas temperaturas, y a la presencia de heladas que se registraron en ese periodo (Figura 1), y al fotoperiodo corto(10).

Durante primavera-verano la producción de forraje es favorecida por las condiciones climáticas que estimularon el buen crecimiento de las gramíneas y leguminosas incrementando la producción(21), aunado a una mayor tasa de aparición y expansión foliar como consecuencia de la mayor temperatura y humedad en el suelo $(10,22)$. Específicamente en el trébol blanco, este comportamiento puede estar también relacionado con la mayor área foliar remanente después del pastoreo, debido a su hábito de crecimiento rastrero, y a la presencia de hojas que le permiten a esta especie interceptar la radiación solar y capturar el dióxido de carbono $(15,23)$.

\section{Radiación interceptada}

Todas las asociaciones registraron la mayor radiación interceptada en primavera-verano $(\mathrm{P}<0.05$; Cuadro 3 ) superando a las registradas en otoño e invierno. En general, el porcentaje promedio de radiación solar interceptada fue de 86, 88, 92 y 93 \% en invierno, otoño, primavera y verano, respectivamente. La estacionalidad en el porcentaje de radiación interceptada, estuvo directamente asociado $\left(r^{2}=0.6\right)$ con la distribución estacional del rendimiento de forraje (Cuadros 1, 4), por lo que a mayor radiación estacional interceptada, mayor rendimiento de forraje, independientemente de la asociación.

Las especies en monocultivo presentaron la menor intercepción de luz durante todas las estaciones del año y el menor rendimiento de forraje. Los datos anteriores revelan que la capacidad de las asociaciones para interceptar la radiación solar depende del porcentaje de conditions in which they grew(20). Most of the adaptations of perennial ryegrass in winter conditions partly explains why some associations were superior to others in autumn-winter, unlike orchardgrass and white clover that had its greatest yields in springsummer. Lower production in autumn-winter (Table 1), can be attributed to low temperatures and the presence of frost that occurred during that period (Figure 1), and the short photoperiod(10).

During spring-summer herbage production is favored by climatic conditions that stimulated the proper growth of grasses and legumes thus increasing production(21), due to a higher rate of emergence and leaf expansion as a result of increased temperature and humidity in the soil $(10,22)$. Specifically in white clover, this behavior may also be related to greater leaf area remaining after grazing, due to their habit of creeping growth, and the presence of leaves that allow this species to trap solar radiation and capture carbon dioxide $(15,23)$.

\section{Intercepted radiation}

All associations registered the highest intercepted radiation in spring-summer $(\mathrm{P}<0.05$; Table 3$)$ surpassing those recorded in autumn and winter. Overall, the average percentage of intercepted solar radiation was $86,88,92$ and $93 \%$ in winter, autumn, spring and summer, respectively. Seasonality in the percentage of intercepted radiation, was directly associated $\left(r^{2}=0.6\right)$ with the seasonal distribution of forage yield (Tables $1,4)$, thus the higher the seasonally intercepted radiation, the higher the herbage yield, regardless of the association. The pure species had the lowest level of light interception during all seasons of the year and thus the lowest herbage yield. The above data shows that the ability of associations to intercept solar radiation depends on the percentage of each specie and associated environmental conditions that they are exposed to during each harvest before growth(20,24,25). 
PRODUCTIVIDAD DE ASOCIACIONES DE OVILLO, BALLICO Y TRÉBOL

Cuadro 3. Radiación interceptada, como promedio estacional, del dosel de diferentes proporciones en la asociación de dos gramíneas con una leguminosa (\%)

Table 3. Intercepted radiation in terms of seasonal average, of the sward canopy with different proportions of associations of two grasses and a legume (\%)

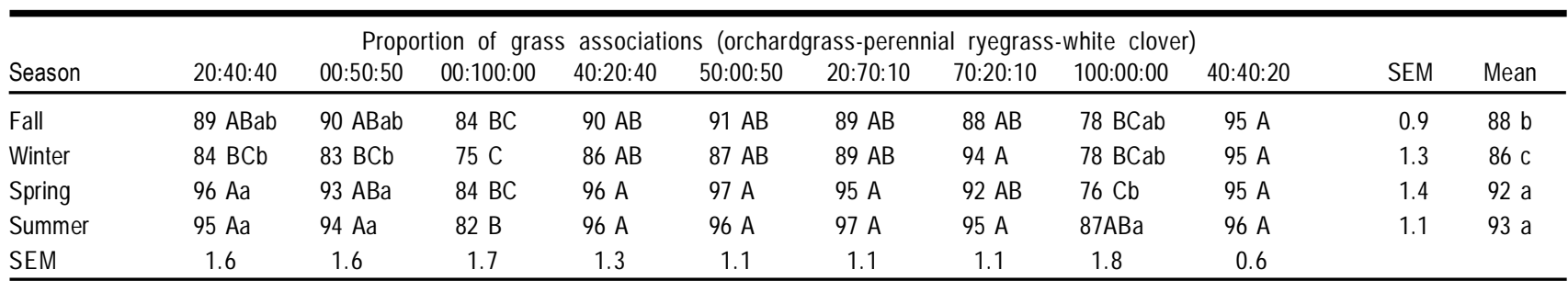

$\mathrm{ABC}$, abc Means with the same capitalized letter per row are not different $(P>0.05)$ and mean with the same lowercase letter along a column are not different $(P>0.05$; Tukey, 0.05$)$.

$\mathrm{SEM}=$ standard error of the mean.

cada especie asociada y de las condiciones ambientales a las que fueron expuestas durante su crecimiento previo a cada cosecha $(20,24,25)$.

Altura de la pradera

La mayor altura de planta promedio se registró en verano ( $38 \mathrm{~cm}$ ), superando en 42,68 y $19 \%$ a otoño, invierno y primavera, respectivamente (Cuadro 4); durante la época invernal, se presentó la menor altura promedio en todos los tratamientos. En tanto, que la mayor altura (42 cm), la registró la asociación 20:70:10 en verano; y la menor altura en todas las estaciones del año la obtuvo la asociación 70:20:10 $(P<0.05)$. En general, la altura promedio de las praderas se afectó significativamente por la estación del año. El monocultivo de ballico perenne fue superior al monocultivo de ovillo, en todas las estaciones del año $(P<0.05)$.

Los rendimientos de forraje estuvieron relacionados ( $\left.r^{2}=0.78\right)$ con la altura de la planta; cuando se presentó un incremento en la altura el rendimiento de forraje fue mayor (60\% de la producción total en primavera-verano). En otoño-invierno las alturas fueron menores aunados a una menor cosecha de forraje (40 \%). Lo anterior, concuerda con la relación positiva que existe entre la altura y rendimiento de materia seca encontrada en otras investigaciones(5).
Sward height

The highest mean sward height was recorded in the summer $(38 \mathrm{~cm})$, exceeding autumn, winter and spring by 42, 68 and $19 \%$, respectively (Table 4). During the winter season, for all treatments the lowest average sward height was found. Meanwhile, the greatest height $(42 \mathrm{~cm})$ was recorded in the 20:70:10 association and was recorded in summer. The lowest sward height in all seasons of the year occurred with the association 70:20:10 ( $P<0.05)$. Overall, the average height of the grasses in the swards was significantly affected by the season. Monoculture of perennial ryegrass was superior to the monoculture of orchardgrass, in all seasons $(P<0.05)$.

Herbage yields were related $\left(r^{2}=0.78\right)$ with sward height; when height increased herbage yield was higher ( $60 \%$ of total production in spring-summer). In autumn and winter sward heights were lower, this was associated with a lower herbage harvested (40\%). This is consistent with the positive correlation between sward height and dry matter yield that has been found in other studies(5).

The associations that included the three species recorded the highest herbage yield. White clover showed a greater persistence throughout the year regardless of seeding density. The amount of herbage produced by perennial ryegrass 
Ever del J. Flores Santiago, et al. / Rev Mex Cienc Pecu 2015;6(3):337-347

Cuadro 4. Altura promedio estacional de las plantas para diferentes proporciones en la asociación de dos gramíneas con una leguminosa $(\mathrm{cm})$

Table 4. Seasonal average sward height with different proportions in the associations of two grasses and a legume $(\mathrm{cm})$

\begin{tabular}{lccccccccccc}
\hline & \multicolumn{8}{c}{ Proportion of grass associations (orchardgrass-perennial ryegrass-white clover) } \\
Season & $20: 40: 40$ & $00: 50: 50$ & $00: 100: 00$ & $40: 20: 40$ & $50: 00: 50$ & $20: 70: 10$ & $70: 20: 10$ & $100: 00: 00$ & $40: 40: 20$ & SEM & Mean \\
\hline Fall & $28 \mathrm{Ab}$ & $28 \mathrm{~A}$ & $29 \mathrm{~A}$ & $28 \mathrm{Aab}$ & $26 \mathrm{Abc}$ & $26 \mathrm{Ab}$ & $25 \mathrm{Ab}$ & $20 \mathrm{Aab}$ & $28 \mathrm{Ab}$ & 0.7 & $26 \mathrm{C}$ \\
Winter & $24 \mathrm{ABb}$ & $25 \mathrm{~A}$ & $25 \mathrm{~A}$ & $25 \mathrm{Ab}$ & $23 \mathrm{ABC}$ & $24 \mathrm{ABb}$ & $19 \mathrm{ABb}$ & $13 \mathrm{Bb}$ & $23 \mathrm{ABb}$ & 0.9 & $22 \mathrm{~d}$ \\
Spring & $39 \mathrm{Aab}$ & $30 \mathrm{AB}$ & $31 \mathrm{AB}$ & $35 \mathrm{Aab}$ & $35 \mathrm{Aab}$ & $34 \mathrm{Aab}$ & $28 \mathrm{ABab}$ & $18 \mathrm{Bb}$ & $34 \mathrm{Aab}$ & 1 & $31 \mathrm{~b}$ \\
Summer & $41 \mathrm{ABa}$ & $32 \mathrm{AB}$ & $36 \mathrm{AB}$ & $39 \mathrm{ABa}$ & $41 \mathrm{ABa}$ & $42 \mathrm{Aa}$ & $38 \mathrm{ABa}$ & $30 \mathrm{Ba}$ & $39 \mathrm{ABa}$ & 1 & $38 \mathrm{a}$ \\
SEM & 2 & 1.2 & 1.4 & 1.7 & 2.3 & 2.4 & 2.4 & 2.1 & 2.2 & \\
\hline
\end{tabular}

$\mathrm{ABC}$, abc Means with the same capitalized letter per row are not different $(P>0.05)$ and mean with the same lowercase letter along a column are not statistically different $(P>0.05 ;$ Tukey, 0.05$)$. $\mathrm{SEM}=$ standard error of the mean.

Los mayores rendimientos de forraje se encontraron en algunas asociaciones que superaron a los monocultivos de los pastos evaluados. El trébol blanco mostró un mayor aporte de forraje cosechado que los pastos evaluados a través del año independientemente de la densidad de siembra. El aporte de forraje por parte del ballico perenne mostró una mayor dependencia a la densidad de siembra aplicada. En todas las asociaciones y monocultivos, el rendimiento de forraje depende de la estación del año. La intercepción de radiación y altura de planta tienen una correlación positiva con rendimiento de forraje en todas las asociaciones y monocultivos.

\section{AGRADECIMIENTOS}

Al Consejo Nacional de Ciencia y Tecnología (CONACyT), por el apoyo económico, que hizo posible la realización de este trabajo. Al Colegio de Postgraduados y en especial al Programa de Ganadería y a la Línea Prioritaria de investigación 11 "Sistemas de Producción Agrícola, Pecuario, Forestal Acuícola y Pesquera" por contribuir en mi formación como profesionista.

\section{LITERATURA CITADA}

1. Améndola R, Castillo E, Martínez PA. Perfiles por país del recurso pastura/forraje. México. FAO. 2005. had the greatest planting density dependence. Herbage yield in all the swards depended on the season of the year. Moreover, light interception and sward height are positively correlated with herbage yield in all the swards.

\section{ACKNOWLEDGEMENTS}

Is thanked the Consejo Nacional de Ciencia y Tecnología (CONACyT) for the financial support that made possible the realization of this work, the Graduate College and especially the Livestock Program and Strategic Research Line 11 titled "Agricultural Production Systems, Livestock, Forestry and Fisheries " for contributing to my training as a professional.

End of english version

2. Sheaffer CC, Taner CB, Kirkham MB. Alfalfa water relations and irrigation. In: Hanson AA et al. editors. Alfalfa and alfalfa improvement. Agron 1988;29(2):373-409.

3. Medrano H, Bota J, Cifre J, Flexas J, Ribas-Carbó M, Gulías J. Eficiencia en el uso del agua por las plantas. Invest Geo 2007; (43): 63-84.

4. Zaragoza EJ, Hernández-Garay A, Pérez PJ, Herrera HJG, Osnaya GF, Martínez HPA, Gonzáles MS et al. Análisis de crecimiento estacional de una pradera asociada alfalfa-pasto ovillo. Téc Pecu Méx 2009;47(2):137-188.

5. Castro RR, Hernández-Garay A, Vaquera HH, Hernández GJ de la Paz, Quero CAR, Enríquez QJ F, Martínez HPA. 
Comportamiento productivo de asociaciones de gramíneas con leguminosas en pastoreo. Rev Fitotec Méx 2012; 35(1):87-95.

6. Karsten HD, Carlassare M. Describing the botanical compositions of a mixed species northeastern U. S. Pasture rotationally grazed by cattle. Crop Sci 2002;42(3):882-889.

7. Scheneiter 0 . Mezclas de especies forrajeras perennes templadas. Jornada de Actualización Técnica en Pasturas Implantadas, Sumidea SA. Generación y evaluación de cultivares de especies forrajeras, INTA. E.E.A Pergamino. 2005: 15-28.

8. Ortiz SC. Colección de monolitos. Montecillo, Texcoco, Edo. México. México: Depto. Génesis de suelos. Edafología, IRENAT. Colegio de Posgraduados; 1997.

9. García E. Modificaciones al sistema de clasificación climática de Köppen. México, DF: Universidad Nacional Autónoma de México; 1988.

10. Velazco ZME, Hernández-Garay A, González HVA, Pérez PJ, Vaquera HH, Galvis SA. Curva de crecimiento y acumulación estacional del pasto ovillo (Dactylis glomerata L). Téc Pecu Méx 2001;39(1):1-14.

11. Velazco ZME, Hernández-Garay A, González HVA. Cambios en componentes del rendimiento de una pradera de Ballico perenne, en respuesta a la frecuencia de corte. Rev Fitotec Méx 2007;30(1):79-87.

12. Hodgson J, Matthew PNP, Matthew C, Lucas RJ. Pasture measurement. In: N Z Pasture Crop Sci. White J, Hodgson J, editors. Auckland, NZ: Oxford Univ Press; 1999:59-65.

13. Adams JE, Arkin GF. A light interception method for measuring row crop ground cover. Soil Sci Soc Am J 1997;41(4): 789-792.

14. SAS Institute. SAS User's Guide: Statistics. 9th ed. Cary NC, USA. SAS Inst. Inc. 2002.

15. Hodgson J. Grazing management. Science into practice. 1rst ed. Harlow, England: Longman Scientific Technical; 1990.
16. Daly MJ, Hunter RM, Green GN, Hunt L. A comparison of multi species pasture with ryegrass-white clover pastures under dry land conditions. Proc NZ Grassland Assoc 1996; 58(1):53-58.

17. MacKenzie BA, Kemp PD, Moot DJ, Matthew C, Lucas RJ. Environmental effects on plant growth and development. In: White J, Hodgson J, editors. NZ Pasture Crop Sci. Auckland, NZ: Oxford Univ Press; 1999:29-44.

18. Lemaire G. Ecophysiology of grasslands Aspects of forage plant populations in grazed swards. Proc Inter Grassland Cong. Brazilian Soc Anim Husbandry. Sociedade Brasileira de Zootecnia. Sau Paulo, Brasil. 2001:29-37.

19. Matthew CG, Val Loo EN, Tom ER, Dawson LA, Care DA. Understandings shoot and root development. Proc Intern Grassland Cong. Sau Paulo. Brasil. 2001:19-27.

20. Da Silva SC, Hernández-Garay A. Manejo del pastoreo en praderas tropicales. Forrajes y su impacto en el trópico. 1era ed. México: Universidad Autónoma de Chiapas; 2010:4362.

21. Mooso GD, Wedin WF. Yield dynamics of canopy components in alfalfa-grass mixtures. Agron J 1990;82(4):696-701.

22. Velazco ZME, Hernández-Garay A, González HVA, Pérez PJ, Vaquera $\mathrm{HH}$. Curvas estacionales de crecimiento del ballico perenne. Rev Fitotec Méx 2002;25(1):97-106.

23. Arne S, Mortensen LM. Growth and regrowth of Phleum pratense, Lolium perenne, Trifolium repens and Trifolium pratense at normal and elevated $\mathrm{CO}_{2}$ concentration. Agr Eco Env 1995;55(1):29-35.

24. Frederick JR, Bauer PJ. Physiological and numerical components of wheat yield. In: Satorre, EH, Slafer GA editors. Wheat, ecology and physiology of yield determination. Nueva York: Foot Products Press; 1999.

25. Horrocks RD, Vallentine JF. Harvested forages. London. USA: Academic Press; 1999. 
